\title{
The terrorist inside my husband's brain
}

Susan Schneider

Williams, BFA

Correspondence to

S. Schneider Williams:

susan@susanschneiderfineart.com

Neurology ${ }^{\circledR}$ 2016;87:1308-1311
I am writing to share a story with you, specifically for you. My hope is that it will help you understand your patients along with their spouses and caregivers a little more. And as for the research you do, perhaps this will add a few more faces behind the why you do what you do. I am sure there are already so many.

This is a personal story, sadly tragic and heartbreaking, but by sharing this information with you I know that you can help make a difference in the lives of others.

As you may know, my husband Robin Williams had the little-known but deadly Lewy body disease (LBD). He died from suicide in 2014 at the end of an intense, confusing, and relatively swift persecution at the hand of this disease's symptoms and pathology. He was not alone in his traumatic experience with this neurologic disease. As you may know, almost 1.5 million nationwide are suffering similarly right now.

Although not alone, his case was extreme. Not until the coroner's report, 3 months after his death, would I learn that it was diffuse LBD that took him. All 4 of the doctors I met with afterwards and who had reviewed his records indicated his was one of the worst pathologies they had seen. He had about $40 \%$ loss of dopamine neurons and almost no neurons were free of Lewy bodies throughout the entire brain and brainstem.

Robin is and will always be a larger-than-life spirit who was inside the body of a normal man with a human brain. He just happened to be that 1 in 6 who is affected by brain disease.

Not only did I lose my husband to LBD, I lost my best friend. Robin and I had in each other a safe harbor of unconditional love that we had both always longed for. For 7 years together, we got to tell each other our greatest hopes and fears without any judgment, just safety. As we said often to one another, we were each other's anchor and mojo: that magical elixir of feeling grounded and inspired at the same time by each other's presence.

One of my favorite bedrock things we would do together was review how our days went. Often, this was more than just at the end of the day. It did not matter if we were both working at home, traveling together, or if he was on the road. We would discuss our joys and triumphs, our fears and insecurities, and our concerns. Any obstacles life threw at us individually or as a couple were somehow surmountable because we had each other.

When LBD began sending a firestorm of symptoms our way, this foundation of friendship and love was our armor.

The colors were changing and the air was crisp; it was already late October of 2013 and our second wedding anniversary. Robin had been under his doctors' care. He had been struggling with symptoms that seemed unrelated: constipation, urinary difficulty, heartburn, sleeplessness and insomnia, and a poor sense of smell-and lots of stress. He also had a slight tremor in his left hand that would come and go. For the time being, that was attributed to a previous shoulder injury.

On this particular weekend, he started having gut discomfort. Having been by my husband's side for many years already, I knew his normal reactions when it came to fear and anxiety. What would follow was markedly out of character for him. His fear and anxiety skyrocketed to a point that was alarming. I wondered privately, Is my husband a hypochondriac? Not until after Robin left us would I discover that a sudden and prolonged spike in fear and anxiety can be an early indication of LBD.

He was tested for diverticulitis and the results were negative. Like the rest of the symptoms that followed, they seemed to come and go at random times. Some symptoms were more prevalent than others, but these increased in frequency and severity over the next 10 months.

By wintertime, problems with paranoia, delusions and looping, insomnia, memory, and high cortisol levels_-just to name a few-were settling in hard. Psychotherapy and other medical help was becoming a constant in trying to manage and solve these seemingly disparate conditions.

I was getting accustomed to the two of us spending more time in reviewing our days. The subjects though were starting to fall predominantly in the category of fear and anxiety. These concerns that used to 
have a normal range of tenor were beginning to lodge at a high frequency for him. Once the coroner's report was reviewed, a doctor was able to point out to me that there was a high concentration of Lewy bodies within the amygdala. This likely caused the acute paranoia and out-of-character emotional responses he was having. How I wish he could have known why he was struggling, that it was not a weakness in his heart, spirit, or character.

In early April, Robin had a panic attack. He was in Vancouver, filming Night at the Museum 3. His doctor recommended an antipsychotic medication to help with the anxiety. It seemed to make things better in some ways, but far worse in others. Quickly we searched for something else. Not until after he left us would I discover that antipsychotic medications often make things worse for people with LBD. Also, Robin had a high sensitivity to medications and sometimes his reactions were unpredictable. This is apparently a common theme in people with LBD.

During the filming of the movie, Robin was having trouble remembering even one line for his scenes, while just 3 years prior he had played in a full 5month season of the Broadway production Bengal Tiger at the Baghdad Zoo, often doing two shows a day with hundreds of lines_-and not one mistake. This loss of memory and inability to control his anxiety was devastating to him.

While I was on a photo shoot at Phoenix Lake, capturing scenes to paint, he called several times. He was very concerned with insecurities he was having about himself and interactions with others. We went over every detail. The fears were unfounded and I could not convince him otherwise. I was powerless in helping him see his own brilliance.

For the first time, my own reasoning had no effect in helping my husband find the light through the tunnels of his fear. I felt his disbelief in the truths I was saying. My heart and my hope were shattered temporarily. We had reached a place we had never been before. My husband was trapped in the twisted architecture of his neurons and no matter what I did I could not pull him out.

In early May, the movie wrapped and he came home from Vancouver-like a 747 airplane coming in with no landing gear. I have since learned that people with LBD who are highly intelligent may appear to be okay for longer initially, but then, it is as though the dam suddenly breaks and they cannot hold it back anymore. In Robin's case, on top of being a genius, he was a Julliard-trained actor. I will never know the true depth of his suffering, nor just how hard he was fighting. But from where I stood, I saw the bravest man in the world playing the hardest role of his life.

Robin was losing his mind and he was aware of it. Can you imagine the pain he felt as he experienced himself disintegrating? And not from something he would ever know the name of, or understand? Neither he, nor anyone could stop it-no amount of intelligence or love could hold it back.

Powerless and frozen, I stood in the darkness of not knowing what was happening to my husband. Was it a single source, a single terrorist, or was this a combo pack of disease raining down on him?

He kept saying, "I just want to reboot my brain." Doctor appointments, testing, and psychiatry kept us in perpetual motion. Countless blood tests, urine tests, plus rechecks of cortisol levels and lymph nodes. A brain scan was done, looking for a possible tumor on his pituitary gland, and his cardiologist rechecked his heart. Everything came back negative, except for high cortisol levels. We wanted to be happy about all the negative test results, but Robin and I both had a deep sense that something was terribly wrong.

On May 28th, he was diagnosed with Parkinson disease (PD).

We had an answer. My heart swelled with hope. But somehow I knew Robin was not buying it.

When we were in the neurologist's office learning exactly what this meant, Robin had a chance to ask some burning questions. He asked, "Do I have Alzheimer's? Dementia? Am I schizophrenic?" The answers were the best we could have gotten: No, no, and no. There were no indications of these other diseases. It is apparent to me now that he was most likely keeping the depth of his symptoms to himself.

Robin continued doing all the right things - therapy, physical therapy, bike riding, and working out with his trainer. He used all the skills he picked up and had finetuned from the Dan Anderson retreat in Minnesota, like deeper 12-step work, meditation, and yoga. We went to see a specialist at Stanford University who taught him self-hypnosis techniques to quell the irrational fears and anxiety. Nothing seemed to alleviate his symptoms for long.

Throughout all of this, Robin was clean and sober, and somehow, we sprinkled those summer months with happiness, joy, and the simple things we loved: meals and birthday celebrations with family and friends, meditating together, massages, and movies, but mostly just holding each other's hand.

Robin was growing weary. The parkinsonian mask was ever present and his voice was weakened. His left hand tremor was continuous now and he had a slow, shuffling gait. He hated that he could not find the words he wanted in conversations. He would thrash at night and still had terrible insomnia. At times, he would find himself stuck in a frozen stance, unable to move, and frustrated when he came out of it. He was beginning to have trouble with visual and spatial abilities in the way of judging distance and depth. His loss of basic reasoning just added to his growing confusion. 
It felt like he was drowning in his symptoms, and I was drowning along with him. Typically the plethora of LBD symptoms appear and disappear at random times - even throughout the course of a day. I experienced my brilliant husband being lucid with clear reasoning 1 minute and then, 5 minutes later, blank, lost in confusion.

Prior history can also complicate a diagnosis. In Robin's case, he had a history of depression that had not been active for 6 years. So when he showed signs of depression just months before he left, it was interpreted as a satellite issue, maybe connected to PD.

Throughout the course of Robin's battle, he had experienced nearly all of the 40-plus symptoms of LBD, except for one. He never said he had hallucinations.

A year after he left, in speaking with one of the doctors who reviewed his records, it became evident that most likely he did have hallucinations, but was keeping that to himself.

It was nearing the end of July and we were told Robin would need to have inpatient neurocognitive testing done in order to evaluate the mood disorder aspect of his condition. In the meantime, his medication was switched from Mirapex to Sinemet in an effort to reduce symptoms. We were assured Robin would be feeling better soon, and that his PD was early and mild. We felt hopeful again. What we did not know was that when these diseases "start" (are diagnosed) they have actually been going on for a long time.

By now, our combined sleep deficit was becoming a danger to both of us. We were instructed to sleep apart until we could catch up on our sleep. The goal was to have him begin inpatient testing free of the sleep-deprived state he was in.

As the second weekend in August approached, it seemed his delusional looping was calming down. Maybe the switch in medications was working. We did all the things we love on Saturday day and into the evening, it was perfect-like one long date. By the end of Sunday, I was feeling that he was getting better.

When we retired for sleep, in our customary way, my husband said to me, "Goodnight, my love," and waited for my familiar reply: "Goodnight, my love."

His words still echo through my heart today.

Monday, August 11, Robin was gone.

After Robin left, time has never functioned the same for me. My search for meaning has replicated like an inescapable spring throughout nearly every aspect of my world, including the most mundane.

Robin and I had begun our unplanned research on the brain through the door of blind experience. During the final months we shared together, our sights were locked fast on identifying and vanquishing the terrorist within his brain. Since then, I have continued our research but on the other side of that experience, in the realm of the science behind it.
Three months after Robin's death, the autopsy report was finally ready for review. When the forensic pathologist and coroner's deputy asked if I was surprised by the diffuse LBD pathology, I said, "Absolutely not," even though I had no idea what it meant at the time. The mere fact that something had invaded nearly every region of my husband's brain made perfect sense to me.

In the year that followed, I set out to expand my view and understanding of LBD. I met with medical professionals who had reviewed Robin's last 2 years of medical records, the coroner's report, and brain scans. Their reactions were all the same: that Robin's was one of the worst LBD pathologies they had seen and that there was nothing else anyone could have done. Our entire medical team was on the right track and we would have gotten there eventually. In fact, we were probably close.

But would having a diagnosis while he was alive really have made a difference when there is no cure? We will never know the answer to this. I am not convinced that the knowledge would have done much more than prolong Robin's agony while he would surely become one of the most famous test subjects of new medicines and ongoing medical trials. Even if we experienced some level of comfort in knowing the name, and fleeting hope from temporary comfort with medications, the terrorist was still going to kill him. There is no cure and Robin's steep and rapid decline was assured.

The massive proliferation of Lewy bodies throughout his brain had done so much damage to neurons and neurotransmitters that in effect, you could say he had chemical warfare in his brain.

One professional stated, "It was as if he had cancer throughout every organ of his body." The key problem seemed to be that no one could correctly interpret Robin's symptoms in time.

I was driven to learn everything I could about this disease that I finally had the name of. Some of what I learned surprised me.

One neuropathologist described LBD and PD as being at opposite ends of a disease spectrum. That spectrum is based on something they share in common: the presence of Lewy bodies - the unnatural clumping of the normal protein, $\alpha$-synuclein, within brain neurons. I was also surprised to learn that a person is diagnosed with LBD vs PD depending on which symptoms present first.

After months and months, I was finally able to be specific about Robin's disease. Clinically he had PD, but pathologically he had diffuse LBD. The predominant symptoms Robin had were not physical-the pathology more than backed that up. However you look at it-the presence of Lewy bodies took his life.

The journey Robin and I were on together has led me to knowing the American Academy of Neurology 
and other groups and doctors. It has led me to discover the American Brain Foundation, where I now serve on the Board of Directors.

This is where you come into the story.

Hopefully from this sharing of our experience you will be inspired to turn Robin's suffering into something meaningful through your work and wisdom. It is my belief that when healing comes out of Robin's experience, he will not have battled and died in vain. You are uniquely positioned to help with this.

I know you have accomplished much already in the areas of research and discovery toward cures in brain disease. And I am sure at times the progress has felt painfully slow. Do not give up. Trust that a cascade of cures and discovery is imminent in all areas of brain disease and you will be a part of making that happen.

If only Robin could have met you. He would have loved you - not just because he was a genius and enjoyed science and discovery, but because he would have found a lot of material within your work to use in entertaining his audiences, including the troops. In fact, the most repeat character role he played throughout his career was a doctor, albeit different forms of practice.

You and your work have ignited a spark within the region of my brain where curiosity and interest lie and within my heart where hope lives. I want to follow you. Not like a crazed fan, but like someone who knows you just might be the one who discovers the cure for LBD and other brain diseases.

Thank you for what you have done, and for what you are about to do.

\section{DISCLOSURE}

Susan Schneider Williams serves on the Board of Directors for the American Brain Foundation (americanbrainfoundation.org) but reports no disclosures relevant to the manuscript. Go to Neurology.org for full disclosures. 


\title{
Neurology
}

\author{
The terrorist inside my husband's brain \\ Susan Schneider Williams \\ Neurology 2016;87;1308-1311 \\ DOI 10.1212/WNL.0000000000003162
}

This information is current as of September 26, 2016

\section{Updated Information \& Services}

\section{Supplementary Material}

Citations

Subspecialty Collections

\section{Permissions \& Licensing}

Reprints including high resolution figures, can be found at: http://n.neurology.org/content/87/13/1308.full

Supplementary material can be found at: http://n.neurology.org/content/suppl/2016/09/26/WNL.0000000000003 162.DC1

This article has been cited by 2 HighWire-hosted articles: http://n.neurology.org/content/87/13/1308.full\#\#otherarticles

This article, along with others on similar topics, appears in the following collection(s):

All Cognitive Disorders/Dementia

http://n.neurology.org/cgi/collection/all_cognitive_disorders_dementia Assessment of cognitive disorders/dementia

http://n.neurology.org/cgi/collection/assessment_of_cognitive_disorder s_dementia

Dementia with Lewy bodies

http://n.neurology.org/cgi/collection/dementia_with_lewy_bodies

Parkinson's disease/Parkinsonism

http://n.neurology.org/cgi/collection/parkinsons_disease_parkinsonism

Tremor

http://n.neurology.org/cgi/collection/tremor

Information about reproducing this article in parts (figures,tables) or in its entirety can be found online at:

http://www.neurology.org/about/about_the_journal\#permissions

Information about ordering reprints can be found online:

http://n.neurology.org/subscribers/advertise

Neurology ${ }^{\circledR}$ is the official journal of the American Academy of Neurology. Published continuously since 1951, it is now a weekly with 48 issues per year. Copyright @ 2016 American Academy of Neurology. All rights reserved. Print ISSN: 0028-3878. Online ISSN: 1526-632X.

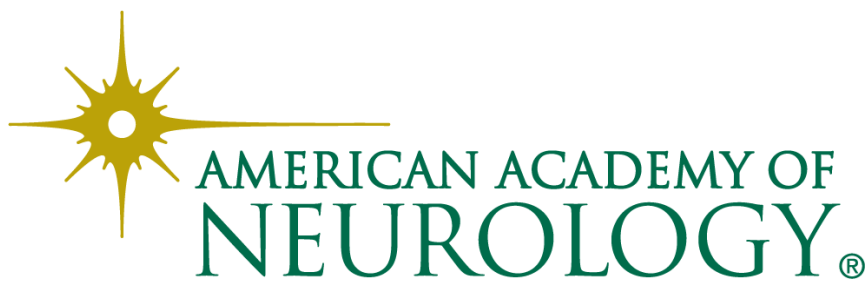

